\title{
PENYIMPANGAN PARTISIPASI MASYARAKAT DALAM PENATAAN KAWASAN CAGAR BUDAYA
}

\author{
Budi Kurniawan ${ }^{1}$ \\ ${ }^{1}$ Magister Perencanaan Wlayah dan Kota, Universitas Gadjah Mada, Indonesia
}

DOI: 10.23917/humaniora.v22i1.9183

Submit: 11 November 2019. Revisi: 12 Januari 2021. Diterima: 18 January 2021. Available Online: 27 January 2021. Periode Terbit: Februari 2021.

\begin{tabular}{l}
\hline Keywords \\
\hline cultural heritage, \\
structuring, \\
participation \\
\\
\\
\hline Corresponding \\
Author \\
\hline Budi Kurniawan \\
Universitas Gadjah \\
Mada \\
Indonesia \\
Email: \\
bk.arch99@yahoo.com \\
Telp: \\
+62813 78879000
\end{tabular}

Abstract

In preserving cultural heritage based on community participation, the community engangement and their support greatly influence the outcome. This study aims to examine community participation in the activities of structuring cultural heritage carried out through the mechanism of subsidies. We employ research method using a case study approach to gain an in-depth understanding of the form and the influence of community participation in each stage of the preservation program and the factors that influence it. Based on the study, we found that there was a form of deviation of community participation, both in the implementation stage and in the postactivity utilization stage. The deviations in participation occur as a result of a mismatch between the objectives of the activity and the actual needs of the community. As for the factors that influence the occurrence of irregularities in community participation, the come from the internal form of motivation, commitment and attitude, as well as external factors in the form of activity management, and policy aspects.

\begin{tabular}{ll}
\hline Kata Kunci & Abstrak \\
\hline partisipasi, & Dalam kegiatan konservasi dan penataan kawasan cagar \\
warisan budaya, & budaya berdasarkan partisipasi masyarakat, keterlibatan dan \\
penataan & dukungan masyarakat di setiap tahapan kegiatan sangat \\
& mempengaruhi pencapaian. Kajian ini bertujuan untuk \\
& mengetahui partisipasi masyarakat dalam kegiatan penataan \\
& kawasan cagar budaya yang dilakukan melalui mekanisme \\
& subsidi. Metode penelitian yang digunakan adalah pendekatan \\
& studi kasus untuk mendapatkan pemahaman yang mendalam \\
& tentang bentuk dan pengaruh partisipasi masyarakat pada \\
& setiap tahapan program dan faktor-faktor yang \\
& mempengaruhinya. Berdasarkan penelitian ditemukan adanya \\
& bentuk penyimpangan partisipasi masyarakat baik pada tahap \\
& pelaksanaan maupun pada tahap pemanfaatan pasca kegiatan. \\
& Dalam konteks kasus yang diteliti, penyimpangan partisipasi \\
& terjadi akibat ketidaksesuaian antara tujuan kegiatan dengan \\
& kebutuhan masyarakat yang sebenarnya. Adapun faktor-faktor \\
& yang mempengaruhi terjadinya penyimpangan dalam \\
partisipasi masyarakat bersumber dari internal berupa
\end{tabular}


motivasi, komitmen dan sikap, serta faktor eksternal berupa pengelolaan kegiatan, dan aspek kebijakan.

\section{PENDAHULUAN}

Berbagai literatur menyatakan pentingnya keterlibatan masyarakat dalam perumusan kebijakan dan perencanaan kegiatan konservasi (Chan, 2016; Dian \& Abdullah, 2013; Wong, 2018; Yung \& Chan, 2011). Perumusan kebijakan dalam pelestarian kawasan melalui pemberian insentif harus mencerminkan kebutuhan nyata dari masyarakat yang berpartisipasi (Radzuan \& Ahmad, 2016). Selanjutnya, Radzuan, Fukami, et al. (2014) menyatakan bahwa kegiatan konservasi dengan pemberian insentif akan efektif jika ada keterkaitan kebijakan insentif dengan kebutuhan komunitas (masyarakat). Partisipasi masyarakat merupakan faktor utama yang menentukan keberhasilan dan efektivitas program.

Arnstein (1969) menggambarkan tingkatan partisipasi masyarakat sebagai anak tangga yang dimulai dari manipulation hingga citizen control. Pada tingkatan terbawah Arnstein (1969) menggambarkannya sebagai manipulation atau partisipasi manipulatif sebagai bentuk penyimpangan yang dilakukan pihak yang berkuasa (pemerintah) terhadap masyarakat. Selanjutnya, Pretty (1995) juga menggambarkan tipologi partisipasi berdasarkan tingkatannya, namun dari perspektif partisipan. Pada tingkat terbawah terdapat manipulative participation, yang kurang lebih menggambarkan hal yang sama dengan manipulation pada Arnstein (1969). Akan tetapi, teori-teori tersebut tidak mengantisipasi bilamana terjadi hal sebaliknya, yang penyimpangan atau manipulasi dapat juga terjadi dan dilakukan oleh partisipan (masyarakat).

Terkait partisipasi masyarakat dalam kegiatan konservasi cagar budaya dan pengembangan wisata budaya, terdapat beberapa literatur yang menggambarkan dengan perspektif yang beragam. Tosun (1999) membagi partisipasi masyarakat dalam 3 kelompok, yaitu coercive participation (partisipasi karena keterpaksaan), passive participation (partisipasi pasif), dan spontaneous participation (partisipasi spontan). Selanjutnya, Chan (2016) melakukan adaptasi pada tangga Arnstein, dan menggambarkan tingkat partisipasi sebagai sebuah proses yang dimulai dari education hingga self management. Adapun Spiridon \& Sandu (2015) juga membagi tipologi tingkat partisipasi beradasarkan adaptasi dari berbagai literatur yang digunakan, dimulai dari involuntary participation by use hingga functional participation. Namun, bagaimana bila partisipasi masyarakat terjadi dalam bentuk yang berupa gabungan atau kombinasi dari berbagai tipologi yang ada?

Kajian ini mencoba menggambarkan dan menelusuri bentuk dan pengaruh partisipasi masyarakat dalam konteks kasus kegiatan konservasi berbasis partisipasi masyarakat melalui pemberian subsidi yang dilakukan di Kota Lama Sawahlunto. Penelitian terdahulu telah dilakukan oleh Febra (2016) yang menyatakan bahwa partisipasi masyarakat dalam program konservasi di Kota Lama Sawahlunto tinggi (29,2\%) dan sangat tinggi (33,8\%). Akan tetapi, kajian tersebut 
tidak menjelaskan tingkatan mana partisipasi masyarakat berdasarkan tipologi yang ada. Selain itu, bagaimana menjelaskan hubungan antara temuan tingkat partisipasi yang tinggi dengan fenomena "penyimpangan partisipasi" dan adanya unsur "keterpaksaan" yang ditemukan pada partisipasi masyarakat dalam kegiatan pelestarian di Kota Lama Sawahlunto yang telah dilakukan dalam kurun waktu $2007-2012$.

\section{METODE}

Penelitian ini menggunakan pendekatan studi kasus (Yin, 2012) untuk menggambarkan bagaimana bentuk dan pengaruh partisipasi masyarakat pada kegiatan penataan dan pelestarian kawasan Kota Lama Sawahlunto (How), dan faktor-faktor yang mempengaruhi partisipasi masyarakat dalam kegiatan tersebut (Why). Fokus penelitian adalah partisipasi masyarakat dalam Kegiatan Penataan dan Pemugaran Fasad pada permukiman eks buruh tambang Tanah Lapang yang berlokasi di Kawasan Kota Lama Sawahlunto yang telah dilaksanakan dalam kurun waktu 2007-2012.

Data dikumpulkan melalui observasi langsung di lapangan dan wawancara mendalam (in-depth interview) terhadap masyarakat yang berpartisipasi dan pegawai pemerintah selaku pengelola kegiatan. Kajian dilakukan berdasarkan runut waktu atau menurut tahapan program (pra-program, aktivitas dan pelaksanaan, dan pasca program). Analisis data dilakukan dengan melakukan triangulasi menurut sumber data.

\section{HASIL}

Hasil penelitian terdiri dari tiga bagian pembahasan menurut tahapan program; Pertama, pada tahapan pra-program akan digambarkan bagaimana kondisi kawasan yang akan dilakukan kegiatan penataan dan konservasi, bagaimana partisipasi masyarakat dalam perumusan kebijakan dan perencanaan dan berbagai aktivitas pra program, serta apa yang melatarbelakangi "tingginya" partisipasi masyarakat (Febra, 2016) dalam kegiatan tersebut. Kedua, adalah tahap pelaksanaan dan pengawasan untuk menggambarkan bentuk partisipasi masyarakat dan pengaruhnya terhadap hasil (output) kegiatan tersebut; dan ketiga, pada tahap pasca program akan digambarkan bagaimana partisipasi masyarakat dalam pemanfaatan dan fenomena atau kecenderungan yang terjadi, serta dampaknya terhadap tujuan kegiatan pelestarian. Pada setiap bagian akan diterangkan faktor-faktor yang memengaruhinya.

\section{Partisipasi Masyarakat pada Tahap Pra-Program}

Permasalahan utama yang melatarbelakangi upaya pemerintah untuk melakukan intervensi berupa kegiatan penataan kawasan adalah menurunnya kualitas visual kawasan berdasarkan hasil kajian yang dilakukan Pemerintah Daerah bersama LPM ITB (Kuswartojo, 2001), yang pada kawasan Kota Lama telah terjadi perubahan bentuk dan karakteristik bangunan cagar budaya sehingga 
nilai sejarah \& budaya yang ada ditakutkan akan rusak dan hilang. Selain itu, perkembangan hunian yang ada juga tidak tertata dan cenderung kumuh (Cherish, 2014)

Namun demikian, sesungguhnya fenomena yang terjadi pada kawasan permukiman buruh Tanah Lapang adalah terjadinya perubahan fungsi (Hanafi et al., 2017). Permukiman tersebut yang pada awalnya berfungsi sebagai asrama atau camp untuk buruh tambang pada masa penjajahan Belanda, kemudian pada perkembangannya berubah menjadi hunian untuk karyawan tambang PTBA (hunian keluarga). Perubahan bentuk yang terjadi pada bangunan adalah proses alami dari bentuk adaptasi penghuni terhadap kebutuhan mereka akan hunian yang layak. Adaptasi dilakukan dengan melakukan penambahan ruang dan penambahan fungsi penunjang lainnya (KM, pagar, kanopi, dll) sehingga akhirnya menutupi fasad asli bangunan.

Sesuai dengan visi pemerintah untuk menjadikan Kawasan Kota Lama sebagai kawasan wisata budaya, maka intervensi perlu dilakukan. Cherish (2014) menyatakan bahwa sesuai amanat UU Cagar Budaya No. 11 Tahun 2010 dan visi Pemerintah untuk menjadikan Kota Sawahlunto sebagai Kota Wisata Tambang, kebijakan untuk melakukan konservasi di Kawasan Kota Lama sangat perlu dilakukan untuk memelihara nilai sejarah dan budaya serta pengembangan wisata budaya. Namun demikian, berdasarkan temuan di lapangan melalui observasi dan wawancara, ditemukan bahwa kebijakan konservasi dirumuskan dengan pendekatan top down, yang keterlibatan masyarakat dalam perumusan kebijakan dan pengambilan keputusan sangat rendah, hal tersebut berpotensi menimbulkan konflik pada pelaksanaannya (Radzuan et al., 2015). Selain itu, kebijakan yang dibuat juga cenderung kurang mempertimbangkan kebutuhan sesungguhnya dari masyarakat, akibatnya terjadi ketidak sesuaian antara tujuan program dengan apa yang dibutuhkan masyarakat (Radzuan,Ahmad, et al., 2014). Selain itu, kebijakan yang dibuat juga cenderung kontroversi karena masyarakat diharuskan untuk membongkar penambahan ruang yang ada. Kebijakan baru dan kontroversi cenderung akan menghadapi permasalahan dalam pelaksanaannya (Winarno, 2014).

Selanjutnya, pada aktivitas studi dan perencanaan, ditemukan juga bahwa perencanaan dibuat dengan kurang melibatkan masyarakat atau komunitas pada kawasan tersebut. Berdasarkan keterangan masyarakat, pada kegiatan perumusan kebijakan dan perencanaan hanya diwakili oleh beberapa orang tokoh masyarakat saja. Adapun pada kegiatan konservasi, perencanaan seharusnya dibuat bersamasama melibatkan semua stakeholder yang berkepentingan terutama warga atau komunitas yang menempati bangunan pada kawasan tersebut (Villiers, 2009). Akibatnya, pada pelaksanaan sosialisasi kegiatan banyak terjadi protes dan penolakan oleh masyarakat. Masyarakat mempersoalkan pembongkaran ruang yang menyebabkan hunian mereka menjadi lebih sedikit dan terbatas. Selain itu, mereka juga tidak menyukai tampilan fasad bangunan yang direncanakan. 
Meskipun pada akhirnya hampir keseluruhan masyarakat Tanah Lapang menyetujui untuk mengikuti kegiatan penataan dan pemugaran fasad tersebut. Berdasarkan temuan di lapangan, fenomena yang terjadi sesungguhnya adalah adanya ketertarikan atau motivasi masyarakat untuk memperoleh dana subsidi (participation for incentives) (Pretty, 1995; Spiridon \& Sandu, 2015), serta adanya unsur keterpaksaan untuk berpartisipasi (coesive participation) (Tosun, 1999).

Unsur keterpaksaan masyarakat berpartisipasi dalam kegiatan penataan dan pemugaran fasad bangunan disebabkan oleh faktor aspek kepemilikan (Hocking et al., 2008), yang bangunan yang mereka tempati sesungguhnya secara sah dimiliki oleh perusahaan Tambang PTBA, dan masyarakat menghuni bangunan pada kawasan tersebut dengan status hak pakai atau pinjam pakai.

Tingginya "tingkat" partisipasi yang ditemukan oleh Febra (2016) lebih disebabkan oleh motivasi masyarakat mendapatkan subsidi dan adanya unsur keterpaksaan meskipun perlu adanya kajian lanjutan yang lebih mendalam untuk menyimpulkan hal tersebut.

\section{Partisipasi Masyarakat pada Tahap Pelaksanaan dan Pengawasan}

Berdasarkan data yang didapatkan dari dokumen laporan kegiatan, ditemukan bahwa keseluruhan bangunan yang dipugar berhasil dikembalikan pada fasad aslinya, yang penambahan ruang yang berada pada bagian depan bangunan telah dibongkar sesuai rencana, sedangkan penambahan bangunan pada bagian samping bangunan "diperbolehkan" sebagai bentuk penggunaan adaptif dengan syarat tidak menutupi fasad asli bangunan.

Namun, ditemukan pula bahwa tingkat kesesuaian antara bentuk fasad pada rencana dan output yang dihasilkan sangat rendah. Kesesuaian antara bentuk fasad rencana-output hanya sebesar $18,4 \%$ (diolah dari laporan pengawas). Pada pelaksanaan pemugaran tersebut ditemukan bahwa sebagian besar masyarakat secara "sengaja" tidak mengikuti gambar fasad dan panduan yang diberikan. Meskipun pada saat pemberian dana subsidi masyarakat sebelum kegiatan pemugaran dilakukan, masyarakat telah diberikan gambar dan guidelines yang harus diikuti, dan kemudian masyarakat yang berpartisipasi diharuskan menanda tangani surat pernyataaan yang pada intinya menyatakan kesediaan untuk mengikuti kesepakatan yang telah dibuat.

Bentuk distorsi atau pelanggaran yang dilakukan pada pelaksanaan pemugaran dapat disimpulkan sebagai bentuk penyimpangan partisipasi masyarakat dalam pelaksanaan kegiatan. Penyimpangan partisipasi dapat disimpulkan sebagai bentuk partisipasi manipulatif atau pelanggaran yang dilakukan secara sengaja oleh partisipan (masyarakat). Hal tersebut cukup berbeda dengan berbagai literatur yang ditemukan, terutama terkait partisipasi manipulatif (Arnstein, 1969; Pretty, 1995).

Berdasarkan data yang diperoleh, banyak faktor yang menyebabkan terjadinya pelanggaran yang dilakukan masyarakat pada pelaksanaan kegiatan. 
Faktor-faktor tersebut dapat berasal dari internal partisipan dan berasal dari eksternal partisipan.

Terkait dengan faktor-faktor internal ditemukan bahwa masyarakat tidak menyukai tampilan fasad yang direncanakan, dan adanya motivasi untuk mengikuti tren dalam hal gaya bangunan (klasik, minimalis, dll.). Selain itu, masyarakat memiliki tingkat komitmen yang rendah dalam pelaksanaan program dimana cukup banyak pelanggaran yang terjadi hanya karena faktor ikut-ikutan. Selain itu, rendahnya pengetahuan \& pemahaman masyarakat terhadap kegiatan konservasi menyebabkan sikap kurang peduli masyarakat terhadap pentingnya upaya pelestarian. Masyarakat belum "melihat" adanya manfaat yang akan didapat melalui kegiatan konservasi yang dilakukan.

Selanjutnya, penyimpangan partisipasi masyarakat pada pelaksanaan kegiatan juga dipengaruhi oleh faktor-faktor eksternal, terutama pengawasan yang dilakukan oleh instansi yang berwenang. Berdasarkan keterangan masyarakat ditemukan bahwa pengawas sangat jarang sekali datang melakukan kunjungan untuk melakukan pemeriksaaan dan memberikan arahan. Bahkan tidak sedikit masyarakat yang menyatakan bahwa pengawasan tidak pernah melakukan kunjungan. Lemahnya pengawasan tersebut juga diakui oleh pengelola kegiatan. Selain itu, faktor eksternal yang mempengaruhi terjadinya penyimpangan adalah legalitas kegiatan, yang kesepakatan antara pemerintah dengan masyarakat hanya dibuat dalam bentuk surat pernyataan yang memiliki kekuatan hukum yang lemah dan tidak terdapat sangsi di dalamnya, yang pada akhirnya mempengaruhi komitmen masyarakat untuk mematuhi ketentuan yang telah disepakati (Hartiningrum et al, 2017).

\section{Partisipasi Masyarakat pada Tahap Pemanfaatan Pasca Program}

Pasca program ditemukan terjadinya kecenderungan kawasan untuk berubah kembali pada kondisi pra program berupa pelanggaran yang dilakukan masyarakat. Hal tersebut diakibatkan oleh rendahnya motivasi dan sikap masyarakat terhadap upaya pelestarian kawasan (Rasoolimanesh et al., 2017; Spiridon \& Sandu, 2015; Wirastari \& Suprihadjo, 2012), dan diakibatkan oleh tingginya tingkat kebutuhan terhadap ruang dan fungsi penunjang lainnya (Hanafi, 2017). Mulai banyak masyarakat melakukan perubahan fasad maupun penambahan ruang atau massa bangunan (infill), membangun pagar dan memasang kanopi (awning). Bentuk-bentuk "pelanggaran" tersebut merupakan bentuk alami respon dan adaptasi terhadap kebutuhan. Masyarakat yang "menambah kembali" ruang beralasan bahwa ruang yang ada sudah tidak mencukupi, terlebih jika ada penambahan anggota keluarga baru. Begitupun halnya dengan membangun pagar yang bertujuan untuk memberi rasa aman pada hunian mereka. Adapun pemasangan kanopi (awning) dibutuhkan sebagai peneduh dari sinar matahari dan hujan. 
Berbagai "pelanggaran" tersebut memiliki efek berantai. Bila salah satu warga melakukannya, maka warga lain akan mengikuti. Terlebih lagi belum ada sistem manajemen pengelolaan dan pengendalian yang baik dari instansi yang berwenang (Hocking, 2008; Nurcahyo, 2015; Roy \& Kalindi, 2017). Setelah program berakhir pada tahun 2012, belum ada lagi program lanjutan dari pemerintah, dan terkesan membiarkan "pelanggaran” yang terjadi. Namun berdasarkan ketrangan pengelola kegiatan, selama ini mereka telah berupaya mempertahankan dan menindak lanjuti pelanggaran yang ada, bahkan melaporkan pada atasan di instansi berwenang, namun sangat jarang ditindak lanjuti. Bidang Peninggalan Bersejarah dan Permuseuman pada Dinas Pariwisata dan Kebudayaan Sawahlunto selaku instansi yang bertanggung jawab terhadap konservasi cagar budaya, mengeluhkan lemahnya komunikasi (Villiers, 2009) dan koordinasi (Hamdi, 2015) dengan instansi lain dan Pemerintah Daerah. Pelestarian Cagar Budaya belum menjadi perhatian dan kepedulian bagi semua pihak, sedangkan dalam upaya konservasi sangat dibutuhkan kerja sama semua pihak yang terkait (Villiers, 2009).

Berdasarkan paparan di atas, dapat disimpulkan bentuk dan pengaruh partisipasi masyarakat dalam penataan dan pelestarian kawasan cagar budaya melalui pemberian subsidi dalam tabel 1 .

Tabel 1 Bentuk dan Pengaruh Partisipasi Masyarakat dalam Penataan Kawasan Cagar Budaya Melalui Pemberian Subsidi

\begin{tabular}{|c|c|c|}
\hline & Bentuk partisipasi & $\begin{array}{c}\text { Pengaruh terhadap } \\
\text { kegiatan }\end{array}$ \\
\hline $\begin{array}{l}\text { Partisipasi dalam peru- } \\
\text { musan kebijakan \& } \\
\text { perencanaan }\end{array}$ & $\begin{array}{lr}\text { Rendahnya } & \text { keterlibatan } \\
\text { masyarakat dalam perumu- } \\
\text { san kebijakan } \\
\text { partisipatif). } & \text { Kebijakan } \\
\text { dibuat dengan pendekatan } \\
\text { top-down. }\end{array}$ & $\begin{array}{l}\text { Adanya ketidak sesuaian } \\
\text { antara tujuan program } \\
\text { dengan aspirasi dan kebu- } \\
\text { tuhan sesungguhnya dari } \\
\text { masyarakat }\end{array}$ \\
\hline $\begin{array}{l}\text { Partisipasi dalam } \\
\text { pelaksanaan }\end{array}$ & $\begin{array}{l}\text { Rendahnya komitmen dan } \\
\text { motivasi masyarakat dalam } \\
\text { upaya pelestarian, serta } \\
\text { lemahnya pengawasan yang } \\
\text { dilakukan. Partisipasi yang } \\
\text { tinggi lebih didasari oleh } \\
\text { motivasi mendapatkan sub- } \\
\text { sidi dan adanya unsur } \\
\text { keterpaksaan }\end{array}$ & $\begin{array}{l}\text { Terjadi penyimpangan } \\
\text { partisipasi masyarakat } \\
\text { dengan tidak mengikuti } \\
\text { gambar dan pedoman yang } \\
\text { diberikan, serta motivasi } \\
\text { masyarakat untuk mengi- } \\
\text { kuti tren bentuk fasad. Se- } \\
\text { hingga pada akhirnya hasil } \\
\text { yang diharapkan belum } \\
\text { tercapai. }\end{array}$ \\
\hline $\begin{array}{l}\text { Partisipasi dalam pem- } \\
\text { anfaatan }\end{array}$ & $\begin{array}{l}\text { Rendahnya motivasi } \\
\text { masyarakat dalam men- } \\
\text { dukung upaya pelestarian } \\
\text { kawasan, dan tingginya ting- } \\
\text { kat kebutuhan akan ruang. }\end{array}$ & $\begin{array}{l}\text { Terjadi penyimpangan } \\
\text { berupa pelanggaran oleh } \\
\text { masyarakat dengan } \\
\text { menambah atau merubah } \\
\text { kembali bentuk bangunan }\end{array}$ \\
\hline
\end{tabular}

Sumber: Analisisis peneliti, 2019 


\section{PEMBAHASAN}

Temuan pada penelitian ini adalah konsep "penyimpangan partisipasi" sebagai bentuk pelanggaran atau manipulasi yang dilakukan secara sadar dan sengaja oleh partisipan (masyarakat) pada suatu program atau kebijakan, sedangan menurut Arnstein (1969) dan Pretty (1995) partisipasi manipulatif dipandang sebagai manipulasi yang dilakukan oleh pihak yang berkuasa (pemerintah) terhadap masyarakat.

Secara deduktif, penyimpangan partisipasi masyarakat dalam program konservasi merupakan akibat yang ditimbulkan oleh "ketidaksesuaian" antara tujuan program dengan kebutuhan sesungguhnya dari masyarakat (Radzuan, 2014), yang pada akhirnya menyebabkan tidak efektifnya program konservasi melalui pemberian insentif yang dilakukan.

Selanjutnya, hasil kajian ini sependapat dengan Radzuan (2014) bahwa program konservasi melalui pemberian insentif akan efektif bila ada keterkaitan antara tujuan program dengan apa yang menjadi kebutuhan masyarakat dan mendukung penekanan pentingnya keterlibatan masyarakat dalam perumusan kebijakan dan perencanaan dalam program konservasi (Chan, 2016; Dian \& Abdullah, 2013; Villiers, 2009; Wong, 2018; Yung \& Chan, 2011)

Selain itu, kajian ini mempertanyakan temuan oleh Febra (2016) yang menyatakan bahwa tingkat partisipasi masyarakat dalam program pelestarian cukup tinggi. Tidak begitu jelas pada tingkat mana yang dimaksud, sedangkan berdasarkan beberapa literatur (Chan ,2016; Cornwall, 2006; Spiridon \& Sandu, 2016; Tosun, 1999;) tingkat partisipasi diukur berdasarkan tipologi.

Selanjutnya, dalam penelitian ini juga ditemukan fenomena bentuk partisipasi yang merupakan "gabungan" dari partisipasi karena insentif (participation for incentives) (Pretty, 1995) dan partisipasi karena keterpaksaan (coercive participation) (Tosun, 1999), sedangkan dalam berbagai literatur kedua hal tersebut dipisahkan.

\section{SIMPULAN}

Temuan dalam kajian ini menekankan pentingnya keterlibatan masyarakat dalam perumusan kebijakan dan perencanaan kegiatan konservasi agar adanya keterikatan antara tujuan program dengan apa yang dibutuhkan masyarakat sehingga kebijakan yang dibuat dapat memberikan win-win solution dalam menyikapi permasalahan yang ada.

Selain itu, berdasarkan kajian ini ditemukan bahwa ketidaksesuaian antara tujuan kegiatan dengan kebutuhan masyarakat cenderung dapat menimbulkan bentuk penyimpangan partisipasi sebagai bentuk pelanggaran manipulatif yang dilakukan oleh partisipan atau masyarakat. Selain dipengaruhi oleh faktor internal berupa motivasi, komitmen dan sikap masyarakat terhadap kegiatan pelestarian, 
penyimpangan juga dipengaruhi oleh faktor eksternal berupa manajemen kegiatan dan legalitas kebijakan.

\section{DAFTAR PUSTAKA}

Arnstein, S. R. (1969). A Ladder of Citizen Participation. Journal of the American Institute of Planners, 35(4), 216-224. DOI: https: //doi.org. 10.1080/01944363.2018.1559388.

Chan, P. Y. (2016). Community Participation in Heritage Management: A Case in Macau. (Master), Columbia University, New York.

Cherish, R. (2014). Perencanaan Konservasi Kawasan Eks Permukiman Buruh Tambang Batubara di Kota Sawahlunto Sumatera Barat. Jurnal Arsitektur Melayu dan Lingkungan, 1(1), 57-74. https://journal.unilak.ac.id/index.php/arsitektur/scope.

Dian, A. M., \& Abdullah, N. C. (2013). Public Participation in Heritage Sites Conservation in Malaysia: Issues and challenges. Procedia- Social and behaviour science, 101, 248 - 255. https://doi.org/10.24832/kapata.v15i1.523.

Febra, K. (2016). "Partisipasi Masyarakat dalam Pelestarian Bangunan Cagar Budaya di Kawasan Kota Lama Sawahlunto". (Master Thesis), Universitas Andalas, Padang.

Hamdi, M. (2015). Kebijakan Publik: Proses, Analisis, dan Partisipasi. Bogor: Ghalia Indonesia.

Hanafi, M. H., et al. (2017). "Factors Influence on Conservation of Heritage Building in Malaysia." Paper presented at the 2nd International Conference on Social Sciences, Malaysia.

Hartiningrum, W., \& Sulistyono, Y. (2017). Penyimpangan Prinsip Kesantunan pada Teks Pengumuman Karya Siswa Kelas VII SMP Muhammadiyah 4 Sambi TahuN Ajaran 2015/2016: Tinjauan Pragmatik. Jurnal Penelitian Humaniora, 18(2), 95-104.

Hocking, M., et al. (2008). Enhancing our Heritage Toolkit: Assessing management effectiveness of natural World Heritage sites: UNESCO World Heritage Center.

Kuswartojo, T. (2001). Sawahlunto 2020 : Agenda Mewujudkan Kota Wisata Tambang yang Berbudaya. Bandung: Pemerintah Kota Sawahlunto.

Nurcahyo, N. T. (2015). Evaluasi Pengelolaan Cagar Budaya Kota Tambang Sawahlunto. (Thesis), Universitas Gadjah Mada, Yogyakarta.

Pretty, J. (1995). Participatory Learning for Sustainable Agriculture. World Development, 23, 1247-1263. doi:10.1016/0305-750X(95)00046-F

Radzuan, I. S. M., \& Ahmad, Y. (2016). Synthesising an Effective Incentives System in Safeguarding The Heritage Village of Melaka And George Town. Planning Malaysia: Journal of the Malaysian Institute of Planners(5), 157$168 . \quad \mathrm{https}: / / \mathrm{www}$.planningmalaysia.org/index.php/pmj/article/download $/ 200 / 194$

Radzuan, I. S. M., et al. (2014). Incentives for the Conservation of Traditional Ssettlements: Residents' Perception in Ainokura and Kawagoe, Japan (2014). Journal of Tourism and Cultural Change, 13(4), 1-29. https://doi.org/10.1080/14766825.2014.952302 
Radzuan, I. S. M., Fukami, N., \& Ahmad, Y. (2017). Cultural heritage, incentives system and the sustainable community: Lessons from Ogimachi Village, Japan. Geografia-Malaysian Journal of Society and Space, 10(1). DOI: https://doi.org 10.1108/JCHMSD-02-2014-0006

Radzuan, I. S. M., Inho, S., \& Ahmad, Y. (2015). A rethink of the incentives programme in the conservation of South Korea's historic villages. Journal of Cultural Heritage Management and Sustainable Development. DOI 10.1108/JCHMSD-02-2014-0006

Rasoolimanesh, S. M., et al. (2017). Community participation in World Heritage Site conservation and tourism development. Tourism Management, 58(c), 142-153. DOI: $10.5772 / 62293$

Roy, D., \& Kalindi, S. N. (2017). Critical Challenges in Management of Heritage Conservation Projects in India. Journal of Cultural Heritage Management and Sustainable Development, 7(3), 290-307. DOI 10.1108/JCHMSD-032017-0012

Spiridon, P., \& Sandu, I. (2015). Conservation of the Cultural Heritage: From participation to collaboration. ENCATC Journal of Cultural Management \& Policy, 5(1), 43-52. http://www.eesc.europa.eu/?i=portal.en.press-releases. 1570

Tosun, C. (1999). Towards a Typology of Community Participation in the Tourism Development Process. Anatolia, 10, 113-134. Doi:10.1080/13032917.1999.9686975

Villiers, D. J. D. (2009). The Role of Tourism in Heritage and Community Development The Role of Heritage Tourism. Yogyakarta: Gadjah Mada University Press.

Winarno, B. (2014). Kebijakan Publik ( Teori, Proses, dan Studi Kasus ). Yogyakarta: CAPS ( Center of Academic Publishing Service ).

Wirastari, V. A., \& Suprihadjo, R. (2012). Pelestarian Kawasan Cagar Budaya Berbasis Partisipasi Masyarakat (Studi Kasus: Kawasan Cagar Budaya Bubutan, Surabaya). Jurnal Teknik ITS, 1(1), 63-67. Doi: http://dx.doi.org/10.12962/j23373539.v1i1.1026.

Wong, W. H. (2018). "Community Participation in Heritage Management: A Case Study of Hong Kong's Conservation Approaches." (Master Thesis), Anhalt University of Applied Sciences, Dessau, German.

Yin, R. K. (2012). Studi Kasus Desain dan Metode (D. Mudzakir, Trans. 11 ed.). Jakarta: Raja Grafindo Persada.

Yung, E. H. K., \& Chan, E. H. W. (2011). Problem Issues of Public Participation in Built-Heritage Conservation: Two Controversial Cases in Hong Kong. Habitat International, 35(3), 457-466. https://doi.org: http://hdl.handle.net/10397/15028. 